ISSN 1979-5572 (print)

ISSN 2541-6480 (online

http://ejurnal.iainpare.ac.id/index.php/kuriositas

\title{
KURIOSITAS
}

Media Komunikasi Sosial dan Keagamaan

\begin{tabular}{lll}
\hline Volume 11 & No. 2, Desember 2018 & Halaman 145-157 \\
\hline
\end{tabular}

\section{APLIKASI DIGITAL RISALAH ILMU TAJWID DALAM MENINGKATKAN KEMAMPUAN BACA ALQURAN}

\author{
Khaerul $^{1}$, Muhammad Haramain ${ }^{2}$ \\ Institut Agama Islam Negeri Parepare \\ khaerul@stainparepare.ac.id
}

\begin{abstract}
This article discuss the using of risalah of tajwid digital apps in increasing the students of SMA Negeri 4 Pinrang abilities in reading al-Qur'an. The using of risalah of tajwid digital apps was by optimazing the technology of computer that running by risalah of tajwid digital apps, that able to create the learning environment to prepare the options that can stimulated the students to use the potential cognitive. The objectives of this research was to get the empirical data about the students' ability in reading Alquran before and after taught by using risalah digital of tajwid science and to get the empirical data about students' ability in reading Alquran before and after using text book as well as to get the information about the difference in students' level of ability in reading Alquran at the experiment class and the control class. The research design is used nonequivalent control group design, it means that in this design the experiment class nor the control class was not selected randomly.The research results are: (1) The level of students' ability in reading Alquran in the experiment class before the treatment was classified in poor category, however, after given the treatment it was in good category. (2) The level of students' ability in reading Alquran in the control class before the treatment was in poor category, however, after given the treatment it was in good category. (3) There are difference of students' level ability in reading Alquran in the experiment class and the control class.
\end{abstract}

Keyword: Risalah Digital, Tajwid Science, Ability, Reading Al-Qur'an

\begin{abstract}
ABSTRAK
Tujuan Penelitian ini adalah untuk memperoleh data empiris tentang kemampuan baca Alquran peserta didik sebelum dan sesudah diajar menggunakan digital risalah ilmu tajwid dan untuk memperoleh data empiris
\end{abstract}


tentang kemampuan baca Alquran peserta didik sebelum dan sesudah diajar menggunakan buku paket dan untuk memperoleh informasi adakah perbedaan tingkat kemampuan baca Alquran peserta didik pada kelas eksperimen dan kelas kontrol. Desain Penelitian yang digunakan adalah Nonequivalent control group design, yang berarti pada desain kelompok eksperimen maupun kelompok kontrol tidak dipilih secara random. Hasil Penelitian ini adalah: (1) Tingkat kemampuan baca Alquran peserta didik pada kelas eksperimen sebelum diberi perlakuan berada dalam kategori kurang baik, tetapi setelah diberi perlakuan berada dalam kategori baik (2) Tingkat kemampuan baca Alquran peserta didik pada kelas kontrol sebelum diberi perlakuan berada dalam kategori kurang baik, tetapi setelah diberi perlakuan berada dalam kategori baik (3) Terdapat perbedaan tingkat kemampuan baca Alquran peserta didik pada kelas eksperimen dan kelas kontrol.

Kata kunci : Digital Risalah, Ilmu Tajwid, Kemampuan, Baca Al-Qur'an.

\section{PENDAHULUAN}

Alquran merupakan kitab suci umat Islam di seluruh dunia. Alquran adalah mukjizat terbesar yang dimiliki Nabi Muhammad saw. Allah swt. telah menyempurnakan Alquran bahkan di antara kitab-kitab suci yang lain hanya Alquran yang paling sempurna, sebagaimana firman Allah swt dalam Q.S Yunus/10: 37.

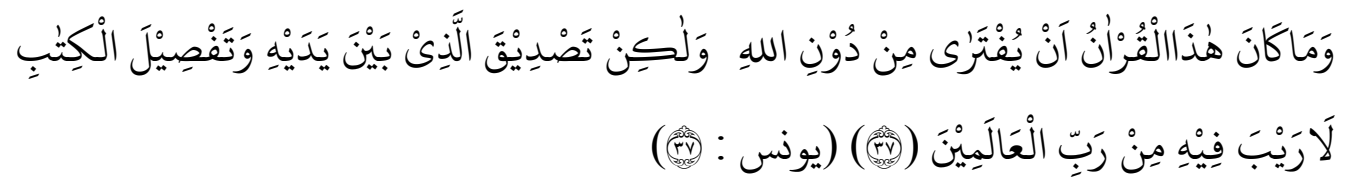

Terjemahnya:

"Dan tidak mungkin Alquran ini dibuat-buat oleh selain Allah; tetapi (AlQur'an) membenarkan (kitab-kitab) yang sebelumnya dan menjelaskan hukum-hukum yang telah ditetapkannya, tidak ada keraguan di dalamnya, (diturunkan) dari Tuhan semesta alam."(Q.S Yunus/10:37).

Membaca dan memahami makna serta mengamalkan isi Alquran menjadi sangat penting, karena Alquran menjadi pedoman hidup bagi semua umat Islam, Allah swt. menurunkan Alquran untuk menghindarkan umat manusia dari kegelapan dan kebodohan menuju cahaya Islam. Salah satu keistimewaan yang dimiliki Alquran dan tidak dimiliki oelh kitab suci lainnya adalah ia akan menjadi pemberi syafa'at pada hari kiamat kepada orang yang senantiasa berinteraksi dengan Alquran . Sebagaimana ditegaskan Rasulullah dalam sabdanya:

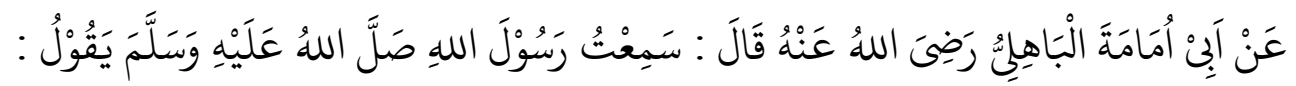

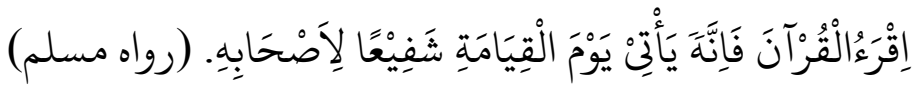


Artinya:

Dari Ab̄̄ Umāmah al-Bāhilì ra berkata : Aku mendengar Rasulullah saw bersabda: "Bacalah Alquran sebab Alquran itu akan datang pada hari kiamat untuk memberi syafa'at kepada para pembacanya." (HR. Muslim No. 1337).(Muslim, 1992)

Mengingat betapa pentingnya Alquran bagi kehidupan manusia, maka pendidikan Alquran menjadi hal yang sangat penting bagi anak-anak sebagai generasi penerus bangsa. Pendidikan merupakan kegiatan seseorang atau kelompok orang ataupun lembaga dalam membantu individu atau sekelompok orang untuk mencapai tujuan pendidikan. Kegiatan bantuan dalam pendidikan dapat berupa pengelolaan pendidikan dan dapat pula berupa kegiatan seperti bimbingan, pengajaran dan latihan.(Wahyudin, 2007)

Teknologi digital dalam pembelajaran baca tulis Alquran merupakan salah satu alat penunjang pembelajaran, keberadaanya sangat dibutuhkan dalam meningkatkan kemampuan membaca Alquran bagi peserta didik. Tujuan utama teknologi pembelajaran adalah untuk memecahkan masalah belajar atau memfasilitasi kegiatan pembelajaran.(Warsita, 2008)

Seiring dengan semakin pesatnya perkembangan ilmu pengetahuan dan teknologi yang mendorong upaya-upaya pembaharuan dalam pemanfaatan hasil-hasil teknologi. Pembelajaran Alquran pun tidak terlepas dari dampak kemajuan teknologi ini. Dengan media ini umat Islam mempunyai pandangan hidup dalam dirinya berdasarkan ajaran agamanya. Terlihat bahwa kebutuhan kepada Alquran semakin meningkat. Peningkatan kebutuhan ini dapat dilihat dengan lahirnya aplikasi pembelajaran Alquran, walaupun kemajuan teknologi setiap hari juga semakin meningkat namun hal ini tidak menyurutkan kreativitas para pecinta Alquran untuk menstimulus orang lain khususnya pada peserta didik agar cinta kepada Alquran dengan melahirkan aplikasi pembelajaran Alquran seperti digital risalah ilmu tajwid untuk memudahkan orang lain dalam mempelajari Alquran.

Pengamatan awal yang dilakukan di SMA Negeri 4 Pinrang menunjukkan bahwa guru yang mengajar baca tulis Alquran hanya menggunakan media buku paket dalam pembelajaran, sehingga mengakibatkan peserta didik tidak dapat mengembangkan potensi yang mereka miliki. Budaya belajar hanya ditandai oleh tulisan dan hafalan, akibatnya pembelajaran baca tulis Alquran hanya dipandang sebagai mata pelajaran menulis dan menghafal, bukan dipandang sebagai mata pelajaran yang urgen dan menyenangkan.

Kemampuan baca Alquran peserta didik SMA Negeri 4 Pinrang khususnya kelas XI IPA 1, menurut pengamatan peneliti setelah melihat hasil tes yang dilaksanakan oleh pendidik menunjukkan hasil yang kurang memuaskan dengan nilai rata-rata 77 yang diperoleh dari hasil ujian tengah semester. Di 
antara kekurangan yang di dapatkan ada beberapa peserta didik yang masih kurang mampu menerapkan hukum-hukum bacaan dengan benar, terkadang bacaan yang suara berdengung tidak di dengungkan malah sebaliknya bacaan yang tidak boleh di baca dengan suara yang berdengung di baca dengan suara berdengung, begitu pula dengan bacaan yang panjang terkadang tidak di panjangkan.

Dari uraian di atas, peneliti tertarik untuk menggunakan Digital Risalah Ilmu Tajwid dalam proses pembelajaran baca tulis Alquran pada SMA Negeri 4 Pinrang khususnya kelas XI IPA I dengan harapan dapat meningkatkan kemampuan peserta didik dalam membaca Alquran .

\section{METODE}

Jenis penelitian ini adalah penelitian Quasi eksperimen. Penelitian eksperimental memanipulasi setidaknya satu variabel independen, mengontrol variabel lain yang relevan, dan mengamati efek pada satu atau lebih variabel tergantung. Sebuah percobaan biasanya melibatkan perbandingan dua kelompok (meskipun beberapa penelitian eksperimental hanya memiliki satu kelompok atau bahkan tiga atau lebih kelompok).

Penelitian eksperimen merupakan metode inti dari model penelitian yang menggunakan pendekatan kuantitatif.(Pd, 2010). Pada penelitian Quasi eksperimen ini desain yang digunakan adalah Nonequivalent control group design, yang berarti pada desain ini kelompok eksperimen maupun kelompok kontrol tidak dipilih secara random.(Sugiyono, 2008).

Penelitian ini akan dilaksanakan dalam lima kali pertemuan. Setiap selesai pemberian treatment maka dilakukan posttes kepada kelompok eksperimen begitu pula dengan kelompok kontrol. Hasil posttes kelompok eksperimen dibandingkan dengan hasil posttes kelompok kontrol maka akan diperoleh perbedaan keduanya. Hal itu dilakukan karena untuk mengetahui apakah penggunaan digital risalah ilmu tajwid ini dapat meningkatkan kemampuan baca Alquran peserta didik.

\section{PEMBAHASAN}

\section{Kemampuan Baca Alquran Peserta Didik Sebelum Menggunakan Digital Risalah Ilmu Tajwid pada Kelas Eksperimen}

Berdasarkan observasi awal dan analisis data yang telah dilakukan, maka kemampuan baca Alquran peserta didik sebelum diajar menggunakan digital risalah ilmu tajwid yaitu:

\section{Indikator kemampuan makhārijul huruf}


Kemampuan makhārijul huruf peserta didik sebelum diajar menggunakan digital risalah ilmu tajwid pada kelas eksperimen, dari 30 peserta didik yang mendapatkan nilai 70-79 berjumlah 25 orang karena dilihat dari segi bacaan kurang fasih makhārijul huruf, contohnya masih didapatkan bacaan peserta didik yang belum mampu membedakan dalam penyebutan huruf hijaiyyah khususnya pada penyebutan huruf isti'lā, sedangkan yang mendapatkan nilai 80-89 berjumlah 5 orang karena dilihat dari segi bacaan fasih makhārijul huruf, contohnya sudah mampu membedakan dalam penyebutan huruf khususnya pada huruf isti'lā dan huruf-huruf yang lain, sehingga dapat disimpulkan bahwa kemampuan makhārijul huruf peserta didik pada kelas eksperimen dengan nilai rata-rata 77,7 berada pada kategori kurang baik. Hal tersebut menunjukkan bahwa peserta didik kurang mampu membaca atau melafazkan Alquran sesuai makhārijul huruf.

\section{Indikator kemampuan tajwid}

Kemampuan tajwid peserta didik sebelum diajar menggunakan digital risalah ilmu tajwid pada kelas eksperimen, dari 30 peserta didik yang mendapatkan nilai 70-79 berjumlah 25 orang karena dilihat dari segi bacaan tajwid kurang benar, contohnya masih didapatkan beberapa peserta didik ketika membaca Alquran belum mampu membedakan mana yang dibaca berdengung dan mana yang tidak berdengung, sedangkan yang mendapatkan nilai 80-89 berjumlah 5 orang karena dilihat dari segi bacaan sesuai tajwid, contohnya sudah mampu membedakan bacaan yang dibaca berdengung dan tidak berdengung, sehingga dapat disimpulkan bahwa kemampuan tajwid peserta didik pada kelas eksperimen dengan nilai rata-rata 78,06 berada pada kategori kurang baik. Hal tersebut menunjukkan bahwa peserta didik kurang mampu membaca atau melafazkan Alquran sesuai ilmu tajwid.

\section{Indikator kemampuan lancar (fasih) dalam membaca Alquran}

Kemampuan lancar membaca Alquran peserta didik sebelum diajar menggunakan digital risalah ilmu tajwid pada kelas eksperimen, dari 30 peserta didik yang mendapatkan nilai 70-79 berjumlah 25 orang karena dilihat dari segi bacaan kurang fasih makhārijul huruf, tajwid kurang benar, dalam membaca masih kurang lancar, contohnya masih didapatkan beberapa peserta didik ketika membaca Alquran tidak sesuai penyebutan huruf hijaiyyah dan tidak mampu membedakan bacaan yang dibaca berdengung dan tidak berdengung sehingga dalam membaca kurang lancar, sedangkan yang mendapatkan nilai 80-89 berjumlah 5 orang karena dilihat dari segi bacaan fasih makhārijul huruf, sesuai tajwid, akan tetapi sedikit ragu-ragu dalam membaca, contohnya mampu membaca Alquran sesuai penyebutan huruf hijaiyyah dan mampu membedakan 
bacaan yang berdengung dan tidak berdengung, sehingga dapat disimpulkan bahwa kemampuan lancar membaca Alquran peserta didik pada kelas eksperimen dengan nilai rata-rata 77,93 berada pada kategori kurang baik. Hal tersebut menunjukkan bahwa peserta didik kurang mampu membaca atau melafazkan Alquran sesuai makhārijul huruf dan ilmu tajwid.

\section{Penggunaan Digital Risalah Ilmu Tajwid dalam Pembelajaran Baca Alquran pada Kelas Eksperimen}

Berdasarkan yang dilakukan peneliti pada penggunaan digital risalah ilmu tajwid yaitu, yang pertama peneliti menyiapkan alat-alat yang dipakai seperti laptop, LCD, setelah menyiapkan alat peneliti membuka proses pembelajaran dengan memberi salam dan menyapa peserta didik. Materi pertama, dalam penelitian ini yaitu hukum bacaan nūn sākinan dan tanwin, materi kedua, Hukum mìm sākinah, materi ketiga, Hukum mìm dan nūn syiddah, materi keempat, Hukum Qalqalah, materi kelima, Hukum mād dan pembagiannya.

Pada penggunaan digital risalah ilmu tajwid ini setelah materi ditampilkan peneliti mengarahkan perhatian peserta didik pada tampilan digital risalah ilmu tajwid untuk membaca, menyimak dan menanyakan materi yang kurang dipahami, setelah itu peneliti menjelaskan materi dan cara membaca hukum bacaan yang dipelajari kemudian mengarahkan peserta didik untuk mencari contoh hukum bacaan yang dipelajari lalu diperintahkan untuk menulis di papan tulis serta membacakannya sesuai hukum bacaan.

Setelah semuanya selesai menulis di papan tulis peneliti kembali bertanya apakah masih ada yang kurang dipahami baik itu hukum bacaan atau cara membacanya? Setelah itu dilanjutkan dengan latihan membaca surah yang ditentukan. Sebelum selesai peneliti mebagikan prin out materi yang dipelajari supaya pembelajaran bisa dipelajari kembali di rumah.

\section{Kemampuan Baca Alquran Peserta Didik Setelah Menggunakan Digital Risalah Ilmu Tajwid pada Kelas Eksperimen}

Berdasarkan hasil tes kemampuan baca Alquran dan analisis data yang telah dilakukan peneliti, maka kemampuan baca Alquran peserta didik setelah diajar menggunakan digital risalah ilmu tajwid yaitu:

Indikator kemampuan makhārijul huruf

Kemampuan makhārijul huruf peserta didik sesudah diberi perlakuan menggunakan digital risalah ilmu tajwid pada kelas eksperimen dari 30 peserta didik yang mendapatkan nilai 70-79 berjumlah 7 orang karena dilihat dari segi bacaan kurang fasih makhārijul huruf, contohnya masih didapatkan bacaan peserta didik yang belum mampu membedakan dalam penyebutan huruf hijaiyyah khususnya pada penyebutan huruf isti'lā, sedangkan yang 
mendapatkan nilai $80-89$ berjumlah 23 orang karena dilihat dari segi bacaan fasih makhārijul huruf, contohnya sudah mampu membedakan penyebutan huruf hijaiyyah khususnya pada huruf isti'lā dan huruf-huruf yang lain, sehingga dapat disimpulkan bahwa kemampuan makhärijul huruf peserta didik pada kelas eksperimen dengan nilai rata-rata 82,83 berada pada kategori baik dan dapat dikatakan meningkat karena sebelum diberi perlakuan (pretes) yang mendapatkan nilai 80-89 berjumlah 5 peserta didik dengan nilai rata-rata 77,7. Hal tersebut menunjukkan bahwa kemampuan peserta didik dalam membaca atau melafazkan Alquran sesuai makhārijul huruf .

\section{Indikator kemampuan tajwid}

Kemampuan tajwid peserta didik sesudah diberi perlakuan menggunakan digital risalah ilmu tajwid pada kelas eksperimen dari 30 peserta didik yang mendapatkan nilai $70-79$ berjumlah 7 orang karena dilihat dari bacaan tajwid kurang benar, contohnya masih didapatkan beberapa peserta didik ketika membaca Alquran belum mampu membedakan mana yang dibaca berdengung dan mana yang tidak berdengung, sedangkan yang mendapatkan nilai 80-89 berjumlah 23 orang karena dilihat dari bacaan sesuai tajwid, contohnya sudah mampu membedakan bacaan yang dibaca berdengung dan tidak berdengung, sehingga dapat disimpulkan bahwa kemampuan tajwid peserta didik pada kelas eksperimen dengan nilai rata-rata 82,03 berada pada kategori baik dan dapat dikatakan meningkat karena sebelum diberi perlakuan (pretes) yang mendapatkan nilai $80-89$ berjumlah 5 peserta didik dengan nilai rata-rata 78,06. Hal tersebut menunjukkan bahwa kemampuan peserta didik dalam membaca atau melafazkan Alquran sesuai ilmu tajwid.

\section{Indikator kemampuan lancar (fasih)}

Kemampuan lancar membaca Alquran peserta didik sesudah diberi perlakuan menggunakan digital risalah ilmu tajwid pada kelas eksperimen dari 30 peserta didik yang mendapatkan nilai $70-79$ berjumlah 7 orang karena dilihat dari segi bacaan kurang fasih makhārijul huruf, tajwid kurang benar, dalam membaca masih kurang lancar, contohnya masih didapatkan beberapa peserta didik ketika membaca Alquran tidak sesuai penyebutan huruf hijaiyyah dan tidak mampu membedakan bacaan yang dibaca berdengung dan tidak berdengung, sehingga dalam membaca kurang lancar, sedangkan yang mendapatkan nilai $80-89$ berjumlah 23 orang karena dilihat dari segi bacaan fasih makhārijul huruf, sesuai tajwid, akan tetapi sedikit ragu-ragu dalam membaca, contohnya mampu membaca Alquran sesuai dalam penyebutan huruf hijaiyyah dan mampu membedakan bacaan yang berdengung dan tidak berdengung, sehingga dapat disimpulkan bahwa kemampuan lancar membaca Alquran peserta didik pada kelas eksperimen dengan nilai rata-rata 82,46 berada pada 
kategori baik dan dapat dikatakan meningkat karena sebelum diberi perlakuan (pretes) yang mendapatkan nilai $80-89$ berjumlah 5 peserta didik dengan nilai rata-rata 77,93. Hal tersebut menunjukkan bahwa kemampuan peserta didik dalam membaca atau melafazkan Alquran sesuai makhārijul huruf dan ilmu tajwid.

Berdasarkan hasil pembahasan di atas terkait penggunaan digital risalah ilmu tajwid pada kelas eksperimen, maka disimpulkan bahwa penggunaan digital risalah ilmu tajwid ini dapat meningkatkan kemampuan baca Alquran peserta didik dengan peningkatan yang cukup signifikan yakni sebesar 13,63\%

\section{Kemampuan Baca Alquran Peserta Didik Sebelum Menggunakan Buku Paket pada Kelas Kontrol}

Berdasarkan observasi awal dan analisis data yang telah dilakukan, maka kemampuan baca Alquran peserta didik sebelum diajar menggunakan buku paket yaitu:

\section{Indikator kemampuan makhārijul huruf}

Kemampuan makhārijul huruf peserta didik sebelum diberi perlakuan menggunakan buku paket pada kelas kontrol dari 30 peserta didik yang mendapatkan nilai 70-79 berjumlah 22 orang karena dilihat dari segi bacaan kurang fasih makhārijul huruf, contohnya masih didapatkan bacaan peserta didik yang belum mampu membedakan dalam penyebutan huruf hijaiyyah khususnya pada penyebutan huruf isti'lā, sedangkan yang mendapatkan nilai 80-89 berjumlah 8 orang karena dilihat dari segi bacaan fasih makhārijul huruf, contohnya sudah mampu membedakan penyebutan huruf hijaiyyah khususnya pada huruf isti'lā dan huruf-huruf yang lain sehingga dapat disimpulkan bahwa kemampuan makhārijul huruf peserta didik pada kelas kontrol dengan nilai ratarata 77,86 berada pada kategori kurang baik. Hal tersebut menunjukkan bahwa peserta didik kurang mampu membaca atau melafazkan Alquran sesuai makhārijul huruf.

\section{Indikator kemampuan tajwid}

Kemampuan tajwid peserta didik sebelum diberi perlakuan menggunakan buku paket pada kelas kontrol dari 30 peserta didik yang mendapatkan nilai 70-79 berjumlah 22 orang karena dilihat dari bacaan tajwid kurang benar, contohnya masih didapatkan beberapa peserta didik ketika membaca Alquran belum mampu membedakan mana yang dibaca berdengung dan mana yang tidak berdengung, sedangkan yang mendapatkan nilai 80-89 berjumlah 8 orang karena dilihat dari bacaan sesuai tajwid, contohnya sudah mampu membedakan bacaan yang dibaca berdengung dan tidak berdengung, sehingga dapat disimpulkan bahwa kemampuan tajwid peserta didik pada kelas 
kontrol dengan nilai rata-rata 78,00 berada pada kategori kurang baik. Hal tersebut menunjukkan bahwa peserta didik kurang mampu membaca atau melafazkan Alquran sesuai ilmu tajwid.

\section{Indikator kemampuan lancar (fasih)}

Kemampuan lancar membaca Alquran peserta didik sebelum diberi perlakuan menggunakan buku paket pada kelas kontrol dari 30 peserta didik yang mendapatkan nilai 70-79 berjumlah 22 orang karena dilihat dari segi bacaan kurang fasih makhārijul huruf, tajwid kurang benar, dalam membaca masih kurang lancar, contohnya masih didapatkan beberapa peserta didik ketika membaca Alquran tidak sesuai penyebutan huruf hijaiyyah dan tidak mampu membedakan bacaan yang dibaca berdengung dan tidak berdengung, sedangkan yang mendapatkan nilai $80-89$ berjumlah 8 orang karena dilihat dari segi bacaan fasih makhārijul huruf, sesuai tajwid, akan tetapi sedikit ragu-ragu dalam membaca, contohnya mampu membaca Alquran sesuai penyebutan huruf hijaiyyah dan mampu membedakan bacaan yang berdengung dan tidak berdengung, sehingga dapat disimpulkan bahwa kemampuan lancar membaca Alquran peserta didik pada kelas kontrol dengan nilai rata-rata 78,00 berada pada kategori kurang baik. Hal tersebut menunjukkan bahwa peserta didik kurang mampu membaca atau melafazkan Alquran sesuai makhārijul huruf dan ilmu tajwid.

\section{Penggunaan Media Buku Cetak dalam Pembelajaran Baca Alquran pada Kelas Kontrol}

Berdasarkan yang dilakukan peneliti pada penggunaan buku paket yaitu, peneliti menuliskan judul materi yang dipelajari pada papan tulis, materi pertama, dalam penelitian ini yaitu hukum bacaan nun sakinan dan tanwin, materi kedua, Hukum mim sakinah, materi ketiga, Hukum mim dan nun syiddah, materi keempat, Hukum Qalqalah, materi kelima, Hukum mād dan pembagiannya.

Pada penggunaan buku paket setelah judul materi ditulis dipapan tulis peneliti mengarahkan perhatian peserta didik untuk menyimak, menulis dan menanyakan materi yang kurang dipahami, setelah itu peneliti menjelaskan materi dan cara membaca hukum bacaan yang dipelajari kemudian mengarahkan peserta didik untuk mencari contoh hukum bacaan yang dipelajari lalu diperintahkan untuk menulis di papan tulis serta membacakannya sesuai hukum bacaan.

Setelah semuanya selesai menulis di papan tulis dan membacanya peneliti kembali bertanya apakah masih ada yang kurang dipahami baik itu hukum bacaan atau cara membacanya? Setelah itu dilanjutkan dengan latihan membaca surah yang ditentukan. 


\section{Kemampuan Baca Alquran Peserta Didik Setelah Menggunakan Buku Paket pada Kelas Kontrol}

Berdasarkan hasil tes kemampuan baca Alquran dan analisis data yang telah dilakukan peneliti, maka kemampuan baca Alquran peserta didik setelah diajar menggunakan buku paket yaitu:

\section{Indikator kemampuan makhārijul huruf}

Kemampuan makhārijul huruf peserta didik sesudah diberi perlakuan menggunakan buku paket pada kelas kontrol dari 30 peserta didik yang mendapatkan nilai 70-79 berjumlah 14 orang karena dilihat dari segi bacaan kurang fasih makhārijul huruf, contohnya masih didapatkan bacaan peserta didik yang belum mampu membedakan dalam penyebutan huruf hijaiyyah khususnya pada penyebutan huruf isti'lā, sedangkan yang mendapatkan nilai 80-89 berjumlah 16 orang karena dilihat dari segi bacaan fasih makhārijul huruf, contohnya sudah mampu membedakan penyebutan huruf hijaiyyah khususnya pada huruf isti'lā dan huruf-huruf yang lain sehingga dapat disimpulkan bahwa kemampuan makhārijul huruf peserta didik pada kelas kontrol dengan nilai ratarata 80 berada pada kategori baik dan dapat dikatakan meningkat karena sebelum diberi perlakuan (pretes) yang mendapatkan nilai $80-89$ berjumlah 8 peserta didik dengan nilai rata-rata 77,86. Hal tersebut menunjukkan bahwa kemampuan peserta didik dalam membaca atau melafazkan Alquran sesuai makhārijul huruf.

\section{Indikator kemampuan tajwid}

Kemampuan tajwid peserta didik sesudah diberi perlakuan menggunakan buku paket pada kelas kontrol dari 30 peserta didik yang mendapatkan nilai 70-79 berjumlah 14 orang karena dilihat dari bacaan tajwid kurang benar, contohnya masih didapatkan beberapa peserta didik ketika membaca Alquran belum mampu membedakan mana yang dibaca berdengung dan mana yang tidak berdengung, sedangkan yang mendapatkan nilai 80-89 berjumlah 16 orang karena dilihat dari bacaan sesuai tajwid contohnya sudah mampu membedakan bacaan yang dibaca berdengung dan tidak berdengung, sehingga dapat disimpulkan bahwa kemampuan tajwid peserta didik pada kelas kontrol dengan nilai rata-rata 80,13 berada pada kategori baik dan dapat dikatakan meningkat karena sebelum diberi perlakuan (pretes) yang mendapatkan nilai 80-89 berjumlah 8 peserta didik dengan nilai rata-rata 78,00. Hal tersebut menunjukkan bahwa kemampuan peserta didik dalam membaca atau melafazkan Alquran sesuai ilmu tajwid.

\section{Indikator kemampuan lancar (fasih)}

Kemampuan lancar membaca Alquran peserta didik sesudah diberi perlakuan menggunakan buku paket pada kelas kontrol dari 30 peserta didik 
yang mendapatkan nilai 70-79 berjumlah 14 orang karena dilihat dari segi bacaan kurang fasih makhārijul huruf, tajwid kurang benar, dalam membaca masih kurang lancar, contohnya masih didapatkan beberapa peserta didik ketika membaca Alquran tidak sesuai penyebutan huruf hijaiyyah dan tidak mampu membedakan bacaan yang dibaca berdengung dan tidak berdengung, sedangkan yang mendapatkan nilai $80-89$ berjumlah 16 orang karena dilihat dari segi bacaan fasih makhārijul huruf, sesuai tajwid, akan tetapi sedikit ragu-ragu dalam membaca, contohnya mampu membaca Alquran sesuai penyebutan huruf hijaiyyah dan mampu membedakan bacaan yang berdengung dan tidak berdengung, sehingga dapat disimpulkan bahwa kemampuan lancar membaca Alquran peserta didik pada kelas kontrol dengan nilai rata-rata 80,3 berada pada kategori baik dan dapat dikatakan meningkat karena sebelum diberi perlakuan (pretes) yang mendapatkan nilai $80-89$ berjumlah 8 peserta didik dengan nilai rata-rata 78,00. Hal tersebut menunjukkan bahwa kemampuan peserta didik dalam membaca atau melafazkan Alquran sesuai makhārijul huruf dan ilmu tajwid.

Berdasarkan hasil pembahasan di atas terkait penggunaan buku paket pada kelas kontrol maka disimpulkan bahwa penggunaan buku paket ini dapat meningkatkan kemampuan baca Alquran peserta didik dengan peningkatan yang cukup signifikan yakni sebesar 6,57\%.

\section{PENGUJIAN HIPOTESIS}

Hasil analisis data yang telah dilakukan oleh peneliti menunjukkan adanya peningkatan kemampuan baca Alquran secara signifikan. Untuk memperoleh data yang komulatif maka analisis data yang terakhir adalah menggunakan uji $\mathrm{t}$ untuk mengetahui tingkat keberhasilan tes yang telah dilakukan.

Berdasarkan uji $\mathrm{t}$ tingkat signifikansi adalah $5 \%$ atau tingkat kepercayaan 95\% (degree of freedom) atau derajat kebebasan adalah $n-1$ atau 30-1=29. Uji dilakukan dua sisi atau dua ekor karena akan diketahui apakah rata-rata pretes sama dengan posttes atau tidak. Perlunya dua sisi dapat diketahui pula dari output SPSS yang menyatakan 2 tailed. Dari tabel $t$ didapat angka $=2,045$.

$\mathrm{t}$ hitung $(2,249)>\mathrm{t}$ tabel $(2,045)$ ( $\mathrm{t}$ hitung lebih besar dari $\mathrm{t}$ tabel) maka $\mathrm{t}$ hitung terletak pada daerah Ho ditolak, oleh karena t hitung terletak pada daerah Ho di tolak, maka dapat disimpulkan bahwa penggunaan digital risalah ilmu tajwid dapat meningkatkan kemampuan baca Alquran peserta didik Kelas XI IPA I SMA Negeri 4 Pinrang, sehingga perlakuan yang diberikan menggunakan digital risalah ilmu tajwid pada kelas eksperimen berhasil secara signifikan. 
Berdasarkan perbandingan nilai probabilitas (sig):

Jika probabilitas $>0,05$ maka Ho diterima

Jika probabilitas $<0,05$ maka Ho ditolak

Pada tabel terlihat bahwa t hitung adalah 2,249 dengan nilai probabilitas 0,032. Oleh karena probabilitas 0,032 <0,05 maka Ho ditolak, yang berarti bahwa penggunaan digital risalah ilmu tajwid dapat meningkatkan kemampuan baca Alquran peserta didik Kelas XI IPA I SMA Negeri 4 Pinrang. Dalam output juga disertakan perbedaan rata-rata (mean) sebesar 1,556 yaitu selisih rata-rata posttes kelas eksperimen dan posttes kelas kontrol.

\section{SIMPULAN}

Berdasarkan hasil penelitian pada kelas eksperimen menggunakan digital risalah ilmu tajwid dan kelas kontrol menggunakan buku paket, maka dapat disimpulkan bahwa:

Tingkat kemampuan baca Alquran peserta didik pada kelas eksperimen sebelum diberi perlakuan berupa penggunaan digital risalah ilmu tajwid berada dalam kategori kurang baik yaitu tingkat kemampuan makhārijul huruf 77,7, tingkat kemampuan tajwid 78,06, tingkat kemampuan lancar membaca Alquran 77,93 . Sedangkan tingkat kemampuan baca Alquran peserta didik pada kelas eksperimen setelah diberi perlakuan berupa penggunaan digital risalah ilmu tajwid berada dalam ketegori baik, dapat dilihat dari tingkat kemampuan makhārijul huruf 82,83, tingkat kemampuan tajwid 82,03, tingkat kemampuan lancar membaca Alquran 82,46, serta mengalami peningkatan, adapun total peningkatan kemampuan baca Alquran peserta didik pada kelas eksperimen setelah menggunakan digital risalah ilmu tajwid yaitu: 13,63\%.

Tingkat kemampuan baca Alquran peserta didik pada kelas kontrol sebelum diberi perlakuan berupa penggunaan buku paket berada dalam kategori kurang baik yaitu tingkat kemampuan makhärijul huruf 77,86, tingkat kemampuan tajwid 78,00, tingkat kemampuan lancar membaca Alquran 78,00. Sedangkan tingkat kemampuan baca Alquran peserta didik pada kelas kontrol setelah diberi perlakuan berupa penggunaan buku paket berada dalam kategori baik, dapat dilihat dari tingkat kemampuan makhārijul huruf 80, tingkat kemampuan tajwid 80,13, tingkat kemampuan lancar membaca Alquran 80,3, serta mengalami peningkatan, adapun total peningkatan kemampuan baca Alquran peserta didik pada kelas kontrol setelah menggunakan buku paket yaitu: $6,57 \%$.

Terdapat perbedaan tingkat kemampuan baca Alquran peserta didik pada kelas eksperimen dan kelas kontrol, adapun perbedaannya yaitu: secara signifikan pada kelas eksperimen total peningkatan kemampuan baca Alquran 
peserta didik yaitu $13,63 \%$ sedangkan pada kelas kontrol total peningkatan kemampuan baca Alquran peserta didik yaitu: 6,57\%. Dapat juga dilihat dari hasil uji $\mathrm{t}$-tes yang menunjukkan $\mathrm{t}$ hitung $(2,249)>\mathrm{t}$ tabel $(2,045)$, hal ini menunjukkan bahwa penggunaan digital risalah ilmu tajwid dapat meningkatkan kemampuan baca Alquran peserta didik Kelas XI IPA I SMA Negeri 4 Pinrang.

\section{REFERENCE}

(1) Efendy, R. (2015, July 8). HEGEMONI EPISTEMOLOGI RASIONAL BARAT DALAM KONSTRUKSI KURIKULUM PAI DI INDONESIA. ALISHLAH : Jurnal Studi Pendidikan, 13

(2) Dalle, H. A. (2015, August 20). WACANA BAHASA INGGRIS BERDASARKAN KETERAMPILAN BERBAHASA KELAS X MAN 2 PAREPARE. AL-ISHLAH : Jurnal Studi Pendidikan, 13

(3) Muslim, I. (1992). Shahih Muslim. Beirut: Darul Fikr. Jilid V.

(4) Pd, T. (2010). Pengantar penelitian pendidikan bagi pengembangan profesi pendidikan \& tenaga kependidikan. Jakarta: Kencana Prenada Media Group.

(5) Rosnah, R. (2015, September 16). PENERAPAN PEMBELAJARAN KOOPERATIF TIPE TEAMS GAMES TOURNAMENTS UNTUK MENINGKATKAN HASIL BELAJAR MATEMATIKA TENTANG PENJUMLAHAN DAN PENGURANGAN BILANGAN PADA SISWA KELAS 1 SD MUHAMMADIYAH 2 PAREPARE. AL-ISHLAH : Jurnal Studi Pendidikan, 13

(6) Saepudin, S. (2015, October 14). KINERJA GURU BAHASA ARAB DALAM PENGEMBANGAN BAHAN AJAR PADA MADRASAH ALIYAH DI PAREPARE. AL-ISHLAH : Jurnal Studi Pendidikan, 13

(7) Sugiyono. (2008). Metode penelitian pendidikan:(pendekatan kuantitatif, kualitatif dan R \& D). Alfabeta.

(8) Wahyudin, D. (2007). Pengantar pendidikan. Jakarta: Universitas Terbuka.

(9) Warsita, B. (2008). Teknologi pembelajaran landasan dan aplikasinya. Jakarta: Rineka Cipta. 